\title{
Genetic Evidence for a Contribution of Native Americans to the Early Settlement of Rapa Nui (Easter Island)
}

\author{
Erik Thorsby * \\ Department of Immunology, University of Oslo and Oslo University Hospital, Oslo, Norway
}

OPEN ACCESS

Edited by:

Franco Biondi,

University of Nevada, USA

Reviewed by:

Irene Tunno,

University of Nevada, USA

Valentí Rull,

Institute of Earth Sciences Jaume

Almera (CSIC), Spain

*Correspondence:

Erik Thorsby

erik.thorsby@medisin.uio.no

Specialty section:

This article was submitted to

Paleoecology

a section of the journal

Frontiers in Ecology and Evolution

Received: 15 May 2016

Accepted: 26 September 2016

Published: 14 October 2016

Citation:

Thorsby E (2016) Genetic Evidence for

a Contribution of Native Americans to

the Early Settlement of Rapa Nui

(Easter Island).

Front. Ecol. Evol. 4:118.

doi: 10.3389/fevo.2016.00118
Available evidence strongly suggests that the first to settle on Rapa Nui were Polynesians arriving from the west around AD 1200-1253. There are, however, also signs of an early contact between Rapa Nui and South America, but genetic evidence of an early contribution of Native Americans to the peopling of Rapa Nui has until recently been lacking. In this review our own genetic studies of blood-derived DNA collected on Rapa Nui since 1971 are summarized. For the first time human molecular genetic data are obtained which strongly suggest that some Native Americans arrived early at Rapa Nui, probably as early as AD 1280-1495. Whether they sailed directly from South America to Rapa Nui on their own rafts or whether they came with Polynesians returning from visits to South America cannot be established by our studies, but the latter possibility may be the most likely given other evidence of early visits by Polynesians to South America. In any case, our data suggest that some Native Americans arrived Rapa Nui not long after its first settlement by Polynesians, but long before the island was discovered by Europeans in 1722. Native Americans may therefore have had an influence on the early human colonization of Rapa Nui and thus on its ecology.

Keywords: Rapa Nui, Easter Island, early settlement, Polynesians, Native Americans, Europeans

\section{INTRODUCTION}

It is now generally accepted that Polynesia was first populated from the west, with peoples who originally came from Southeast Asia, probably around Taiwan. Having reached Samoa and Tonga $\sim 3000$ years before present (BP) (see Figure 1), where they apparently stayed for more than 1000 years, some sailed further east in their double canoes and populated most islands in East Polynesia, including Rapa Nui (Friedlander et al., 2008; Kirch, 2010; Wollstein et al., 2010; Wilmshurst et al., 2011). The timing of the first colonization of Rapa Nui has been much debated. Dates ranging from AD 400-800 have previously been given (references in Hunt and Lipo, 2009). Recent studies based on refined calibrated radiocarbon dates from multiple samples strongly suggest, however, that its first settlement occurred as late as AD 1200-1253 (Wilmshurst et al., 2011).

In contrast, Thor Heyerdahl proposed that East Polynesia, including Rapa Nui, was first populated by Native Americans (Amerindians), arriving from South America $\sim \mathrm{AD} 500$ (Heyerdahl, 1952). Among his arguments were the prevailing winds and ocean currents in the area, Polynesian legends, similarities between old fishing gear found in East Polynesia and on the coast of northern Chile, linguistic and other clues, and the presence of some South American plants in East 


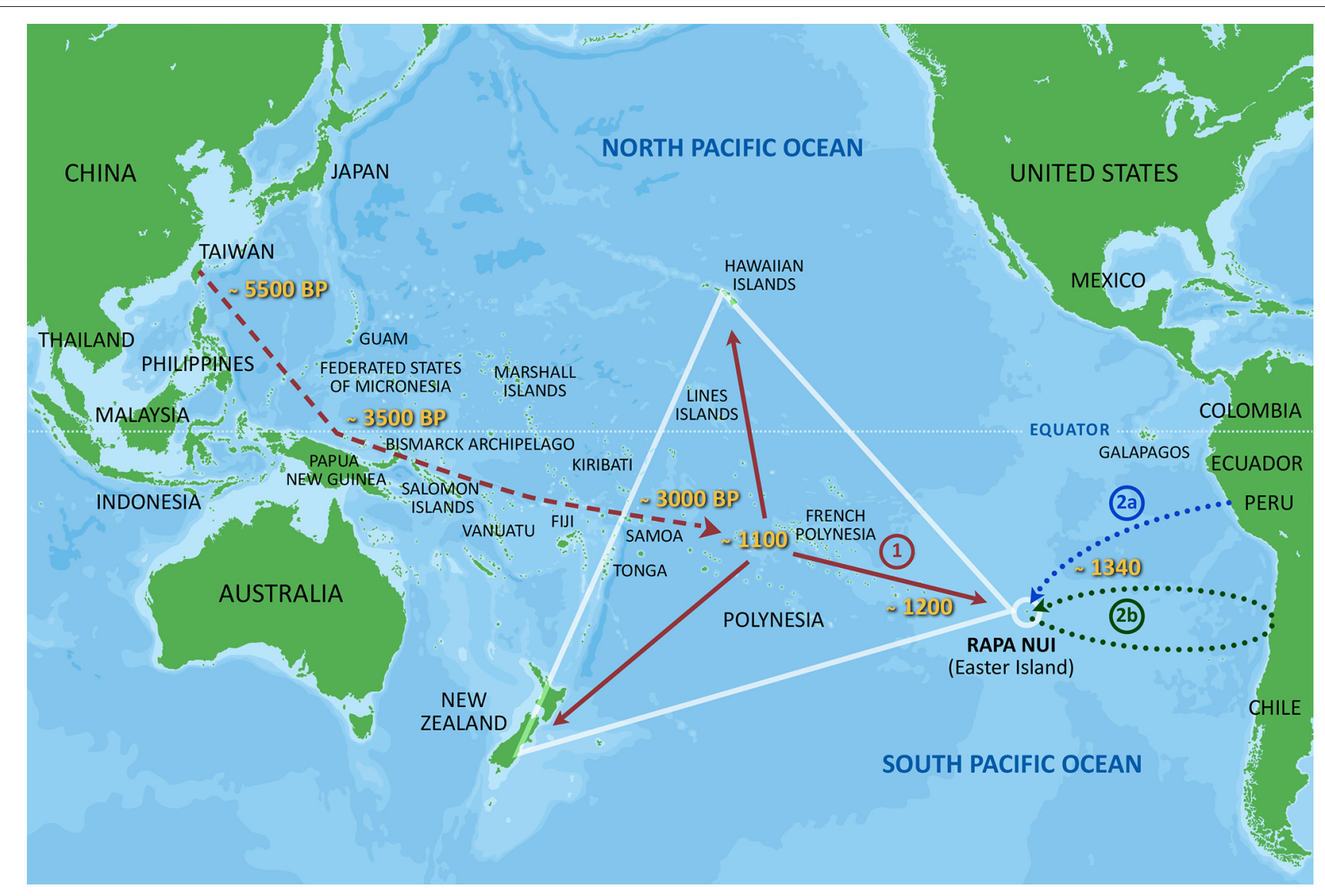

FIGURE 1 | A very schematic illustration of the colonization of the Polynesian triangle of islands. It is generally accepted that Polynesia was first populated with people who came from Southeast Asia, leaving around Taiwan $\sim 5.500$ years before present (BP). They first arrived Samoa and Tonga $\sim 3000$ years BP, from where they sailed further east and arrived at the Society Islands AD 1100 (marked with an interrupted red line). From here they populated most of the Polynesian islands. They reached Rapa Nui AD 1200 (marked with a red line and 1). An early contribution of Native Americans to Rapa Nui $\sim A D 1340$, as strongly suggested by our investigations summarized in this review, is also indicated, arriving either on their own rafts from South America (marked with a dotted blue line and $2 \mathrm{a}$ ), or together with some Polynesians returning from visits to South America (marked with a dotted green line and 2b).

Polynesia and on Rapa Nui such as the Andean sweet potato (Ipomoea batatas) and the bottle gourd (Lagenaria siceraria). He also argued that the giant stone statues, moai, and their platforms, $a h u$, on Rapa Nui (and some other East Polynesian islands) are very similar to some pre-Inca stone statues and platforms in South America, particularly at Tiahuanaco in Bolivia. Thus, Heyerdahl suggested that the first moai and ahu builders on Rapa Nui had brought the exquisite masonry techniques with them from South America. In 1947 he demonstrated by his Kon-Tiki expedition that it was possible to reach East Polynesia with a balsa raft from Peru.

His theory received little support, however, and was to a large extent strongly opposed by most other scholars. Among the evidence against his theory were investigations of mitochondrial DNA (mtDNA) and Y chromosome markers, which demonstrated that Polynesians and Southeast Asians share particular genetic polymorphisms; i.e., genetic variants (Friedlander et al., 2008; Kirch, 2010). Furthermore, mtDNA studies of East Polynesians have not been able to reliably demonstrate a contribution by Native Americans (Bonatto et al., 1996), albeit others claimed that these studies were inconclusive (Cann and Lum, 1996). The presence of some Native American Y chromosomes on Rapa, another island in Polynesia, was assumed to be the result of repatriation following the Peruvian slave raids in Polynesia in the 1860s, which resulted in an admixture of Native American and European genes in the area (Hurles et al., 2003).

Previous investigations on Rapa Nui have also given little support to Heyerdahl's theory, namely that Rapa Nui was first populated by Native Americans. Instead strong evidence of an original Polynesian ancestry has been obtained (Hunt and Lipo, 2011). This includes the results of typing of mtDNA markers from 12 ancient skeletal specimens from the island, dating from $\sim \mathrm{AD} 1100-1868$, which revealed only typical Polynesian mtDNA markers (Hagelberg et al., 1994). Investigations of Rapanui for 18 Alu genetic insertion polymorphisms demonstrated a high genetic affinity to Southeast Asian populations and failed to show an early 
contribution of Native Americans (González-Pérez et al., 2006).

\section{EVIDENCE OF A "PRE-HISTORIC" CONTACT BETWEEN POLYNESIA AND SOUTH AMERICA}

Notwithstanding this evidence of a Polynesian origin of the initial settlement of East Polynesia, there are, however, also clues of a "pre-historic" (i.e., before Europeans discovered Polynesia) contact between East Polynesia and South America. The strongest of these is the presence of the Andean sweet potato in East Polynesia, which has to have been introduced by man, and has been grown on Rapa Nui long before the island was discovered by Europeans (Wallin et al., 2005; Roullier et al., 2013). Recent studies have also detected starch remains of the sweet potato of American origin in dental calculus of human skeletons from Rapa Nui as old as $\sim \mathrm{AD} 1330$ (Tromp and Dudgeon, 2015). Suggestive evidence that the South American bottle gourd was introduced in pre-historic time has also been presented (Kirch, 2010). A pre-historic contact between South America and Polynesia was recently supported by analyses of the remains of some chickens found in El Arenal in the southern part of Chile. The mtDNA of the chickens was found to be of Polynesian type, and radiocarbon investigations showed that the remains dated back to $\sim \mathrm{AD} 1321-1407$, i.e., before Columbus discovered America (Storey et al., 2007). These results were, however, very recently questioned in similar studies performed by others (Thomson et al., 2014). Suggestive evidence of human skeletal remains of pre-Columbian Polynesian ancestry on Mocha Island in Chile has also been reported (Matisoo-Smith and Ramirez, 2010), as well as other evidence of Polynesian presence in South America in pre-Columbian time (Kirch, 2010; Lawler, 2010). Very recently, genomic Polynesian ancestry, but no Native American ancestry, was detected in two ancient skulls of indigenous Botocudos from Brazil (Malaspinas et al., 2015), but more studies are needed to firmly establish that this is the result of a pre-historic voyaging by some Polynesians to South America.

Thus, while there are several clues of a pre-historic contact between East Polynesia and South America, previous studies have failed to demonstrate genetic evidence of an early contribution of Native Americans to Rapa Nui. Instead it was generally assumed that some Native Americans did not reach Rapa Nui until sometime after the island was discovered by Europeans.

\section{INVESTIGATIONS OF RAPANUI HLA MOLECULES}

Human Leucocyte Antigens (HLA) are molecules in our cell membranes which are encoded by some very polymorphic genes at neighboring loci in the HLA genetic complex on chromosome 6 (see Table 1). Soon after their discovery in the early 1960s it was found that these molecules exist in several different variants, which differ greatly in frequencies in different populations. Thus, it was suggested early that serological typing for the different variants of HLA molecules might become informative in anthropological studies. Therefore, in 1971 we collected blood samples from 69 Rapanui who had Rapanui ancestors dating back for many generations and where no foreign admixture was known, based on medical and historical records as well as by interviews (Thorsby et al., 1973; Thorsby, 2012). Most of the individuals belonged to a large family, descendant from Pacomio Maori ( 1816-1909) and his two wives (see Figure 1 in Thorsby, 2012).

By comparing our results with those obtained by others of typing HLA antigens in other populations in this area, however, we could not convincingly demonstrate an early contribution of Native Americans to Rapa Nui (Thorsby et al., 1973). Typing for some blood groups and other genetic markers also did not reveal reliable genetic traces of Native Americans. Since, however, HLA investigations at that time were based on serological typing and had a very low resolution (very few of the HLA variants which became known later could be serologically typed for at that time; see next paragraph), we stored serum samples in liquid nitrogen for future studies when better methods might become available.

\section{GENOMIC HLA INVESTIGATIONS OF RAPANUI DNA}

By 2006 typing of HLA genes by genomic methods had become available and more than 2500 HLA alleles (genetic variants) had been detected which varied in frequency among different populations (Sanchez-Mazas et al., 2011). Thus, we thawed the serum from our 1971 samples and were able to extract DNA from 48 of them.

The results are described in detail elsewhere (Lie et al., 2007; Thorsby, 2012). A total of 11 different HLA haplotypes (the combination of particular HLA alleles carried by the HLA complex on a given chromosome 6) were detected among the investigated individuals. Ten of these haplotypes carried HLA alleles that had previously been observed in Polynesia. Furthermore, all individuals carried one or two HLA haplotypes with typical Polynesian HLA alleles. These results further support an initial Polynesian origin of the population on Rapa Nui.

One haplotype also carried some typical European HLA alleles, which are found in high frequency in Southern Europeans (Solberg et al., 2008). The primary source of these HLA alleles may have been a European crewmember on a ship visiting Rapa Nui in the early 1800s (Thorsby, 2012).

The DNA was also typed for mtDNA markers, which revealed in all investigated samples a combination of mtDNA markers typical of Polynesians. Typing for Y chromosome markers also revealed that most men had haplogroups typical of Polynesians, while five of them had a typical European haplogroup. No traces of Native American mtDNA or Y chromosome markers were found.

\section{NATIVE AMERICAN HLA ALLELES FOUND IN SOME RAPANUI}

Most interesting of the HLA haplotypes, however, were two ( $a$ and $b$, see Table 1) that carried the HLA alleles $A^{*} 02: 12$ and $B^{*}$ 39:05. 
TABLE 1 | Two HLA haplotypes (i.e., combinations of particular alleles at the HLA gene loci in the HLA genetic complex on a given chromosome 6) found in some Rapanui.

\begin{tabular}{|c|c|c|c|c|c|c|}
\hline HLA gene locus & $\boldsymbol{A}$ & $C$ & $B$ & DRB1 & DQA1 & DQB1 \\
\hline HLA haplotype a: & $A^{\star} 02: 12$ & $C * 07: 02: 01$ & $B \star 39: 05$ & DRB1*08:02:01; & DQA1*04:01; & $D Q B 1^{\star} 04: 02$ \\
\hline HLA haplotype b: & $A^{\star} 02: 12$ & $C * 07: 02: 01 ;$ & $B \star 39: 05$ & DRB1*04:03:01; & $D Q A 1^{\star} 03$ & $D Q B 1^{\star} 03: 02$ \\
\hline
\end{tabular}

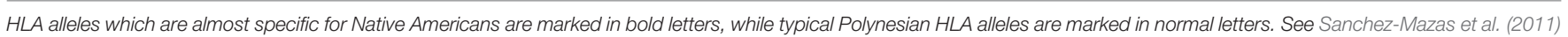
for a description of the nomenclature used for HLA alleles.

These alleles have previously been found almost only among Native Americans and people of Native American ancestry, and are very rare or absent in Polynesian and other non-Native American populations (Solberg et al., 2008; see Figure 2 in Thorsby, 2012).

Thus the $A^{*}$ 02:12 and $B^{*}$ 39:05 alleles may have been generated in America after the migration of an East Asian population via the Bering Strait $\sim 12-15.000$ years BP (Sanchez-Mazas et al., 2011). The other HLA alleles on haplotype $a$ also have their highest frequency in Native Americans, but are also found in some other populations. HLA haplotype $a$ is therefore most probably a haplotype of Native American origin. HLA haplotype $b$ is identical to haplotype $a$ in its A-C-B segment, while the HLA alleles in its DR-DQ segment are much more frequent in Polynesians. Thus, haplotype $b$ is most probably the result of a recombination between the A-C-B segment of a Native American HLA haplotype and the DR-DQ segment of a Polynesian HLA haplotype.

The most important question is when these Native American HLA alleles were introduced on Rapa Nui. Since we had the genealogy of the investigated individuals (see Figure 1 in Thorsby, 2012) we could demonstrate that haplotype $a$ in all probability was introduced in the investigated family by the second wife of Pacomio Maori, who was born on Rapa Nui $\sim 1846$. This is many years before the Peruvian slave trades in the 1860s which resulted in some population mixture in the area. We could not determine how much earlier than in $\sim 1846$ this Native American haplotype was first introduced on the island. Haplotype $b$ is most probably the result of a recombination between a Native American and a Polynesian haplotype, and recombinations between the closely linked loci in the HLA complex are rare events ( $\sim 1 \%$ of meioses). Thus, the presence of this haplotype suggests that the Native American HLA alleles have been present on Rapa Nui for many generations prior to the early 1900s. Together with other data from our genomic HLA investigations (reported in detail in Thorsby, 2012), the combined results of our HLA investigations suggest that some Native Americans reached Rapa Nui before the island was discovered by Europeans in 1722; i.e., in pre-historic time.

\section{ADDITIONAL NATIVE AMERICAN HLA GENES FOUND IN RECENTLY COLLECTED RAPANUI DNA}

In 2008 we collected blood samples from 21 additional Rapanui, who at least had some Rapanui ancestors dating back for several generations. Genomic HLA typing revealed that two individuals had an HLA haplotype carrying some other HLA alleles mainly found in Native Americans. One of these haplotypes carried $B^{*}$ 39:09 and $D R B 1^{*} 08: 02$, the other $B^{*} 15: 07$ (Thorsby et al., 2009; Thorsby, 2012). These two haplotypes carrying typical Native American HLA alleles may also be the result of recombinations with other HLA haplotypes on the island, suggesting an early introduction of the Native American HLA alleles. However, from the known genealogy of the two individuals we cannot establish when these Native American HLA alleles may have been introduced.

The results of investigations of mtDNA and Y chromosome markers were similar to that found in the samples collected in 1971; all individuals carried mtDNA markers typical of Polynesians, and Y chromosome testing revealed only Polynesian or European haplogroups.

\section{GENOME-WIDE INVESTIGATIONS OF THE RAPANUI DNA}

In order to obtain further evidence of an early Native American contribution to the early settlement on Rapa Nui and better information on how early the Native Americans might have reached the island, we initiated a collaboration with the Centre for GeoGenetics at the National History Museum in Copenhagen. DNA from 27 of the Rapanui from whom we had collected blood samples in 1971 and 2008 was genotyped for $>650.000$ SNPs (single nucleotide polymorphic markers). SNPs vary in frequencies between populations, and by comparing the Rapanui SNP data set with similar data sets from other relevant populations we found a mostly Polynesian ancestry, but with an average Native American admixture of $\sim 8 \%$ and an average European admixture of $\sim 16 \%$ among the investigated Rapanui (Moreno-Mayar et al., 2014). These results confirm and extend the results from our genomic HLA typing and again demonstrate a predominant Polynesian genetic background of the investigated Rapanui, but with a significant contribution of Native American and European ancestry.

In some other non-Rapanui Polynesians we found a Native American admixture of only $0.08 \%$, which is significantly lower than among the Rapanui. This finding, which may indicate a higher level of Native American admixture among Rapanui than non-Rapanui Polynesians needs confirmation in other studies before it is possible to speculate on the causes.

The most important question is when the Native American admixture may have taken place on Rapa Nui. As time passes 
by after a population admixture event, the lengths of genetic ancestry segments become smaller because of recombinations in successive generations. By measuring the lengths of SNP ancestry segments of Polynesian, Native American and European origin we found a much higher number of short Native American compared to European ancestry segments, strongly suggesting that Native Americans arrived in pre-historic time. Further, by various methods (see Moreno-Mayar et al., 2014) we could estimate that the Native American admixture took place 1923 generations ago; i.e., AD 1280-1495, or $\sim 1340$. In contrast, the European admixture was estimated to have taken place 2-3 generations ago; i.e., $1850-1895$, or $\sim 1870$. Thus, some Native Americans probably arrived Rapa Nui not long after the first Polynesians arrived in 1200-1253.

\section{COMMENTS AND CONCLUSIONS}

This review summarizes our molecular genetic studies so far carried out using blood-derived DNA collected on Rapa Nui. The results further support an initial Polynesian colonization of the island from the west. However, for the first time human genetic evidence of an early contribution of Native Americans was also found, both by genomic HLA typing and genome-wide investigations of SNPs. By analysis of SNP ancestry tracts the Native American admixture was estimated to have taken place AD 1280-1495, or $\sim 1340$.

The results of our genomic HLA and SNP investigations are in contrast to previous and our own investigations of mtDNA and $\mathrm{Y}$ chromosome markers of Rapanui. One explanation for these contrasting findings is that Native American HLA alleles may have been subject to different selective forces than Native American mtDNA and Y chromosome markers. HLA molecules are of instrumental importance for immune responses and some Native American HLA alleles may therefore have been selected which encode HLA molecules of importance for immune responses against given pathogens on Rapa Nui. Another not mutually exclusive explanation is genetic drift. At the end of the 1800s only $\sim 100$ Rapanui were left on the island. This may cause a genetic bottleneck and thus a more random genetic transmission of genes from one generation to the next, leading to random genetic changes including loss of genetic variants in the population. Uniparental genetic markers like mtDNA and $\mathrm{Y}$ chromosome markers are more sensitive to genetic drift than genes which are inherited from both parents (see also Thorsby, 2012).

Our results need confirmation in studies of ancient DNA from the island. We tried to extract ancient DNA from Rapanui skeletal remains available at the Kon-Tiki museum in Oslo, but the DNA turned out to be of insufficient quality. Many skeletal remains exist on the island, but it has so far been difficult to obtain the necessary permissions from the local community to obtain access to small pieces of bone for studies of ancient DNA.

A tentative summary of available data for the early colonization of Polynesia, including the results of our own investigations, is schematically illustrated in Figure 1. The initial colonization from Southeast Asia via Melanesia to Samoa and
Tonga and the Society Islands is indicated with a dotted red line, while the later continuation to Rapa Nui $\sim A D 1200$ is marked with a red line and 1 in the figure. Our finding of a contribution by Native Americans to Rapa Nui $\sim$ AD 1340 is also indicated. How the Native Americans may have reached Rapa Nui is unknown. There are at least two, not mutually exclusive possibilities (see also Thorsby, 2012). One, marked by a dotted blue line and 2a in the figure, is that some Native Americans sailed directly to Rapa Nui on their own Kon-Tiki like rafts from South America. This was recently proven possible by the KonTiki 2 expedition from Callao to Rapa Nui. The other possibility is that some Polynesians sailed further east from central East Polynesia or Rapa Nui, reaching South America, but returned to Rapa Nui taking some Native Americans (and possibly the sweet potato etc.) with them. This possibility is marked by a dotted green line and $2 \mathrm{~b}$ in the figure. Because of several signs of early visits of Polynesians to South America (mentioned above), the latter possibility may be the most likely. Storey et al. (2007) reported traces of visits by Polynesians to the coast of Chile $\sim \mathrm{AD} 1321-1407$. If this timing is proven correct it fits well with our estimates for the first arrival of Native Americans to Rapa Nui $1280-1495$, who may have accompanied some returning Polynesians.

It has been argued that return trips between East Polynesia and South America in ancient boats would be difficult, not only because of the long distance, but also due to difficult wind conditions. Following reconstruction of sea level pressure and wind fields for the South Pacific in the period AD 8001600, Goodwin et al. (2014) were, however, able to describe several likely climate windows for off-wind sailing from Rapa Nui to South America, including $1260-1290$ and 1400-1440, and for off-wind sailing in the opposite direction 1220-1260 and $1440-1460$. Thus, in these periods the wind conditions may have been particularly favorable for return trips from East Polynesia or Rapa Nui to South America, which coincide well with our estimates for when some Native Americans first arrived at Rapa Nui.

Since our studies strongly suggest that some Native Americans arrived on Rapa Nui not long after the first settlement by Polynesians from the west, Native Americans may have contributed to the early human colonization on the island. This may have included an influence on the ecology of the island (see Rull et al., 2016), as well as its cultural development such the art of moai and ahu building.

\section{AUTHOR CONTRIBUTIONS}

The author confirms being the sole contributor of this work and approved it for publication.

\section{FUNDING}

Oslo University Hospital, Inven2, the University of Oslo, the Lundbeck Foundation, the Danish National Research Foundation, Consejo Nacional de Ciencia y Technologica and the Swiss National Science Foundation. 


\section{ACKNOWLEDGMENTS}

The studies summarized here are the result of collaboration between many participants. Their names appear from previous reports from our studies on Rapa Nui (Thorsby et al., 1973; Lie et al., 2007; Thorsby et al., 2009; Thorsby, 2012; MorenoMayar et al., 2014). All are again gratefully acknowledged for a most fruitful collaboration for many years, without which it would have been impossible to carry out these

\section{REFERENCES}

Bonatto, S. L., Redd, A. J., Salzano, F. M., and Stoneking, M. (1996). Lack of ancient Polynesian-Amerindian contact. Am. J. Hum. Genet. 59, 253-256.

Cann, R. L., and Lum, J. K. (1996). Mitochondrial myopia: reply to Bonatto et al. Am. J. Hum. Genet. 59, 256-258.

Friedlander, J. S., Friedlander, F. R., Reed, F. A., Kidd, K. K., Kidd, J. R., Chambers, G. K., et al. (2008). The genetic structure of Pacific islanders. PLoS Genet. 4:e19. doi: 10.1371/journal.pgen.0040019

González-Pérez, E., Esteban, E., Via, M., García-Maro, C., Hernández M., and Moral, P. (2006). Genetic change in the Polynesian population of Easter Island: evidence from Alu insertion polymorphisms. Ann. Hum. Genet. 70, 829-840. doi: 10.1111/j.1469-1809.2006.00293.x

Goodwin, I. D., Browning, S. A., and Anderson, A. J. (2014). Climate windows for Polynesian voyaging to New Zealand and Easter Island. Proc. Natl. Acad. Sci. U.S.A. 111, 14716-14721. doi: 10.1073/pnas.1408918111

Hagelberg, E., Quevedo, S., Turbon, D., and Clegg, J. B. (1994). DNA from ancient Easter Islanders. Nature 369, 25-26. doi: 10.1038/369025a0

Heyerdahl, T. (1952). American Indians in the Pacific. The Theory Behind the Kon-Tiki Expedition. London: Allen and Unwin.

Hunt, T. L., and Lipo, C. P. (2009). Revisiting Rapa Nui (Easter Island) "Ecocide". Pac. Sci. 63, 601-616. doi: 10.2984/049.063.0407

Hunt, T. L., and Lipo, C. P. (2011). The Statues that Walked. New York, NY: Free Press, Simon and Schuster.

Hurles, M. E., Maund, E., Nicholson, J., Bosch, E., Renfrew, C., Sykes, B. C., et al. (2003). Native American Y chromosomes in Polynesia: the genetic impact of the Polynesian slave trade. Am. J. Hum. Genet. 72, 1282-1287. doi: 10.1086/ 374827

Kirch, P. V. (2010). Peopling of the Pacific: a holistic anthropological perspective. Ann. Rev. Anthropol. 39, 131-148. doi: 10.1146/annurev.anthro.012809.104936

Lawler, A. (2010). Beyond Kon-Tiki: did Polynesians sail to South America? Science 328, 1344-1347. doi: 10.1126/science.328.5984.1344

Lie, B. A., Dupuy, B. M., Spurkland, A., Fernández-Viña, M. A., Hagelberg, E., and Thorsby, E. (2007). Molecular genetic studies of natives on Easter Island: evidence of an early European and Amrindian contribution to the Polynesian gene pool. Tissue Antigens 69, 10-18. doi: 10.1111/j.1399-0039.2006. 00717.x

Malaspinas, A. S., Lao, O., Schroeder, H., Rasmussen, M., Raghavan, M., Moltke, I., et al. (2015). Two ancient human genomes reveal Polynesian ancestry among the indigenous Botocudos of Brazil. Curr. Biol. 24, R1035-R1037. doi: 10.1016/j.cub.2014.09.078

Matisoo-Smith, E., and Ramirez, J. M. (2010). Human skeletal evidence of Polynesian presence in South America? Metric analyses of six crania from Mocha Island, Chile. J. Pac. Arch. 1, 76-88.

Moreno-Mayar, J. V., Rasmussen, S., Seguin-Orlando, A., Rasmussen, M., Liang, M., Flåm, S. T., et al. (2014). Genome-wide ancestry patterns in Rapanui suggest pre-European admixture with Native Americans. Curr. Biol. 24, 2518-2525. doi: 10.1016/j.cub.2014.09.057

Roullier, C., Benoit, L., McKey, D. B., and Lebot, V. (2013). Historical collections reveal patterns of diffusion of sweet potato in Oceania obscured by modern plant movements and recombination. Proc. Natl. Acad. Sci. U.S.A. 110, 2205-2210. doi: 10.1073/pnas.1211049110

Rull, V., Cañellas-Boltà, N., Margalef, O., Pla-Rabes, S., Sáez, A., and Giralt, S. (2016). Three millennia of climatic, ecological, and cultural change on Easter Island: an integrative overview. Front. Ecol. Evol. 4:29. doi: $10.3389 /$ fevo. 2016.00029 studies. I am particularly grateful to Benedicte A. Lie at Dept. of Medical Genetics, University of Oslo, for her thorough contributions to the genomic HLA investigations and to Eske Willerslev and his colleagues at Centre for GeoGenetics, National History Museum of Denmark for the genome-wide investigations of our DNA. I am grateful for valuable comments from Ian Goodwin and to Benedicte A. Lie and Gregor Duncan Gilfillan for careful reading of the manuscript.

Sanchez-Mazas, A., Fernandez-Viña, M., Middleton, D., Hollenbach, J. A., Buhler, S., Di, D., et al. (2011). Immunogenetics as a tool in anthropological studies. Immunology 133, 143-164. doi: 10.1111/j.1365-2567.2011.03438.x

Solberg, O. D., Mack, S. J., Lancaster, A. K., Single, R. M., Tsai, Y., Sanchez-Mazas, A., et al. (2008). Balancing selection and heterogeneity across the classical human leukocyte antigen loci: a meta-analytic review of 497 population studies. Hum. Immunol. 69, 443-464. doi: 10.1016/j.humimm.2008.05.001

Storey, A. A., Ramírez, J. M., Quiroz, D., Burley, D. V., Addison, D. J., Walter, R., et al. (2007). Radiocarbon and DNA evidence for a pre-Columbian introduction of Polynesian chickens to Chile. Proc. Natl. Acad. Sci. U.S.A. 104, 10335-10339. doi: 10.1073/pnas.0703993104

Thomson, V. A., Lebrasseur, O., Austin, J. J., Hunt, T. L., Burney, D. A., Denham, T., et al. (2014). Using ancient DNA to study the origins and dispersal of ancestral Polynesian chickens across the Pacific. Proc. Natl. Acad. Sci. U.S.A. 111, 4826-4831. doi: 10.1073/pnas.1320412111

Thorsby, E. (2012). The Polynesian gene pool: an early contribution by Amerindians to Easter Island. Philos. Trans. R. Soc. Lond. B. Biol. Sci. 367, 812-819. doi: 10.1098/rstb.2011.0319

Thorsby, E., Colombani, J., Dausset, J., Figueroa, F., and Thorsby, A. (1973). "HLA, blood group and serum type polymorphism of natives on Easter Island," in Histocompatibility Testing 1972, eds J. Dausset and J. Colombani. (Copenhagen: Munksgaard), 287-302.

Thorsby, E., Flåm, S. T., Woldseth, B., Dupuy, B. M., Sanchez-Mazas, A., and Fernandez-Vina, M. A. (2009). Further evidence of an Amerindian contribution to the Polynesian gene pool on Easter Island. Tissue Antigens 73, 582-585. doi: 10.1111/j.1399-0039.2009.01233.x

Tromp, M., and Dudgeon, J. V. (2015). Differentiating dietary and nondietary microfossils extracted from human dental calculus: the importance of sweet potato to ancient diet on Rapa Nui. J. Arch. Sci. 54, 54-63. doi: 10.1016/j.jas.2014.11.024

Wallin, P., Stevenson, C. M., and Ladefoged, T. N. (2005). "Sweet potato production on Rapa Nui," in The Sweet Potato in the Oceania: A Reappraisal. Ethnology Monographs, eds C. Ballard, P. Brown, R. M. Bourke, and T. Harwood (Sydney, NSW: Oceania Monograph), 85-88.

Wilmshurst, J. M., Hunt, T. L., Lipo, C. P., and Anderson, A. J. (2011). High-precision radiocarbon dating shows recent and rapid initial human colonization of East Polynesia. Proc. Natl. Acad. Sci. U.S.A. 108, 1815-1820. doi: 10.1073/pnas.1015876108

Wollstein, A., Lao, O., Becker, C., Brauer, S., Trent, R. J., Nürnberg, P., et al. (2010). Demographic history of Oceania inferred from genome-wide data. Curr. Biol. 20, 1983-1992. doi: 10.1016/j.cub.2010.10.040

Conflict of Interest Statement: The author declares that the research was conducted in the absence of any commercial or financial relationships that could be construed as a potential conflict of interest.

The reviewer IT and handling Editor declared their shared affiliation, and the handling Editor states that the process nevertheless met the standards of a fair and objective review.

Copyright (C) 2016 Thorsby. This is an open-access article distributed under the terms of the Creative Commons Attribution License (CC BY). The use, distribution or reproduction in other forums is permitted, provided the original author(s) or licensor are credited and that the original publication in this journal is cited, in accordance with accepted academic practice. No use, distribution or reproduction is permitted which does not comply with these terms. 